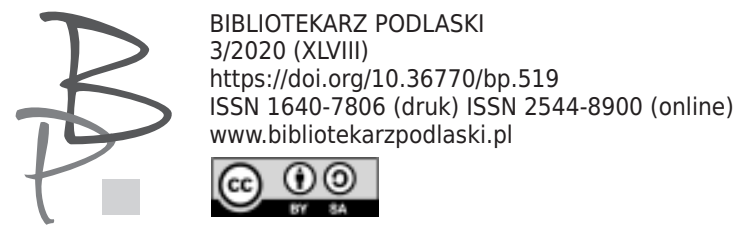

\author{
Barbara Czarnecka* \\ Uniwersytet w Białymstoku \\ https://orcid.org/0000-0003-1813-4720
}

\title{
Twórczość plastyczna Jadwigi Simon-Pietkiewicz w obozie koncentracyjnym w Ravensbrück. Personalizm somatyczny
}

\author{
Jadwiga Simon-Pietkiewicz's artwork at the concentration camp \\ in Ravensbrück. Somatic personalism
}

Abstract: In her article, Barbara Czarnecka analyses Jadwiga Simon-Pietkiewicz's artwork at the concentration camp in Ravensbrück through the prism of somatic personalism. The contemporary discussion on historical matters in the public space is far-reaching and multi-threaded; it is co-created - according to the researcher - by topics not only strictly museum-related, but also those related to unconventional memorial sites, or even memorial (non-)sites in public space, historical tourism and historical restoration movements, historical performance, the role and potential of oral history, contemporary archival work and social archives, and visualizations of history and its presence in the media, not only in historical film and radio, but also, for example, comics, popular music, board games and computer games. Nevertheless, the optimis-

* Barbara Czarnecka - dr hab., literaturoznawczyni; pracuje w Zakładzie Filologicznych Badań Interdyscyplinarnych Wydziału Filologicznego UwB; autorka monografii: Kobiety w lagrze. Zapis doświadczenia (Kraków 2018). 
tic aspect of most of these activities and perspectives is democratization assuming the inclusion of individual voices, faces and bodies, such as those recorded in the works of Simon-Pietkiewicz while in the camp, in the macrohistory discourse.

Keywords: concentration camp in Ravensbrück, somatic personalism, macrohistory discourse.

„Przez cały czas rysowałam...”1

W 2015 roku Muzeum Sztuki Współczesnej w Krakowie „Mocak” opublikowało przekład pracy Jürgena Kaumköttera Śmierć nie ma ostatniego stowa. Sztuka w tragicznych latach 1933-19452. Obszerna albumowa pozycja zawiera zbiór ponad trzystu reprodukcji dokumentów, zdjęć, rysunków związanych z historią nazistowskich represji; clou tej „galerii” stanowi twórczość powstała w niemieckich obozach koncentracyjnych. Na kartach książki pojawiają się szeroko przedstawieni: Marian Ruzamski, Peter Kien, Peter Weiss, Felix Nussbaum, Otto Pankok, Max Beckmann, Yehuda Bacon. Choć nie wszyscy wymienieni tu artyści byli więźniami lagrów, a ich twórczość pozostaje zróżnicowana pod względem formalnym, to jednak łączy ich dążenie do wyrażenia 'czym' i 'jaki' był hitlerowski terror oraz podjęcie tematu jego ofiar (portrety prześladowanych i więźniów to jeden z głównych tematów). Warto dodać, że publikacji nadano odpowiednio wyszukany kształt edytorski, a w tym, co bodaj najważniejsze, osiągnięto świetną jakość reprodukcji. Jak można wywnioskować, tom ten stanowić ma prezentację ,sztuki w tragicznych latach 1933-1945" aspirującą do jak najpełniejszego ujęcia.

1 J. Jaworska, ,Nie wszystek umrę...”. Twórczość plastyczna Polaków w hitlerowskich więzieniach i obozach koncentracyjnych 1939-1945, Warszawa 1975, s. 91.

2 J. Kaumkötter, Śmierć nie ma ostatniego stowa. Sztuka w tragicznych latach 1933-1945, thum. B. Baran, Kraków 2015. Polskie wydanie towarzyszyło ekspozycji „Polska - Izrael - Niemcy” prezentowanej w krakowskim „MOCAK-u”, zaś niemiecki pierwodruk ukazał się w powiązaniu z wystawą „Śmierć nie ma ostatniego słowa” otwartą w styczniu 2015, w Bundestagu dla upamiętnienia siedemdziesiątej rocznicy wyzwolenia Auschwitz. 
Odwołuję się tutaj do pracy Kaumköttera (istotnej i wartościowej) z najważniejszego dla mnie powodu: wśród większości prezentowanych artystów znalazły się tylko dwie szerzej przedstawione artystki, Dinah Gottliebova ${ }^{3}$ i współczesna izraelska rzeźbiarka i performerka Sigalit Landau. Nie wskazano też prac, które odzwierciedlałyby specyficznie kobiece doświadczenie lat 1933-1945, czy stanowiły reprezentację losów więźniarek lagrów.

$\mathrm{Na}$ mapie wszystkich nazistowskich KL istniał tylko jeden obóz niemal w całości przeznaczony dla kobiet (z niewielką sekcją męską) - działający od 1939 do końca kwietnia 1945 roku, położony na obszarze Meklemburgii, odległy $80 \mathrm{~km}$ od Berlina Ravensbrück. Tylko o tym kobiecym lagrze powiedzieć można, że zachował (do około połowy 1943 roku) znośne warunki, późnej przeobrażone w prawdziwą bytową katastrofę. Pozostałe powstawały jako podobozy centralnych obozów dla mężczyzn (tak rozegrało się to w przypadku Auschwitz, Buchenwaldu, Majdanka, Mauthausen, Stutthofu), i w całym czasie ich trwania stanowiły prowizorium, w zasadzie uniemożliwiające więźniarkom jakąkolwiek twórczość. Jednak i w takich, trudnych do wyobrażenia realiach, miała ona miejsce. Halina Ołomucka, by sięgnąć do wyrazistego przykładu (Kaumkötter poświęca artystce jeden krótki akapit), rysowała nie tylko w warszawskim getcie, na Majdanku i w Birkenau (przebywała też w Ravensbrück i Neustad-Glewe), ale i powojenne prace poświęciła Holokaustowi ${ }^{5}$. Trudno nie upomnieć się też o Janinę Tollik (której niemieckie

3 W Auschwitz Dinah Gottlibova na zlecenie Mengele malowała portrety Cyganek i Cyganów z Ziegeunerlager, po wojnie akwarele te stały się częścią zbiorów Muzeum AuschwitzBirkenau. Kiedy Gottlibova (później Babbit) zażądała zwrotu prac, Muzeum odmówiło jej roszczeniom. W odpowiedzi rozpętano szeroką kampanię medialną w sprawie malarki, a Muzeum stało się celem wielu, również niewybrednych, ataków. Historię tę w szerokim kontekście zaprezentowała Lidia Ostałowska w świetnej książce Farby wodne (Wołowiec 2011).

4 Sigalit Landau prezentuje sztukę postpamięci. Jako urodzona już w Jerozolimie córka żydowskich rodziców, którzy przetrwali obozy internowania i pracy przymusowej, interpretuje doświadczenie Holokaustu poprzez formy nowoczesnej, symbolicznej i metaforycznej, rzeźby i performansu.

5 W 2003 roku Muzeum Auschwitz-Birkenau pozyskało siedemdziesiąt prac artystki, liczne są prezentowane na całym świecie, w Holocaust Memorial Museum w Waszyngtonie, w Instytucie Pamięci Yad Vashem w Jerozolimie, Les Invalides w Paryżu, Deutsches Holocaust Museum w Berlinie.

W Birkenau twórczość artystyczną prowadziła także Zofia Bratro, w obozie przebywała od grudnia 1942 do 17 stycznia 1945, rysowała karykatury esesmanów i karty imieninowe dla koleżanek, malowała akwarele o różnej tematyce, J. Jaworska, , Nie wszystek umrę...”. Twórczość plastyczna Polaków w hitlerowskich więzieniach i obozach koncentracyjnych 1939-1945, Warszawa 1975, s. 52; zob. też hasło Zofia Bratro w https://zapisyterroru.pl/dlibra. 
opracowanie nie uwzględnia wcale) - malarka pozostawiła bogatą kolekcję dzieł odtwarzających doświadczenie Brzezinki, między innymi cykle obrazów oświęcimskich, eksponowane w Belgii, Francji, Austrii, Luksemburgu, Wielkiej Brytanii i Szkocji6.

Paradoksalnie - bo trzeba uznać, że w tak dramatycznych okolicznościach każda kreacja stanowiła ewenement - FKL Ravensbrück stał się miejscem owocnym dla twórczości kilku wyjątkowych plastyczek; patrząc jednak inaczej - to właśnie w powiązaniu z tym lagrem „odbierającym” liczne transporty kobiet wykształconych, również w dziedzinie sztuki, należy poszukiwać kobiecej twórczości obozowej. Bogate zbiory prac plastycznych wykonanych podczas osadzenia w Ravensbrück pozostawiły Éliane Jeannin-Garreau, Nina Jirsikova, Jeannette L'Herminier, Violette Rougier-Lecoq, Maja Berezowska, Maria Hiszpańska (wykonała w obozie ponad czterysta rysunków, z czego ocalało kilkanaście ${ }^{7}$ ), Jadwiga Simon-Pietkiewicz ${ }^{8}$. Obszerne zestawienia reprodukcji ich prac znajdują się w aktualnej ekspozycji Muzeum - Miejsca Pamięci Ravensbrück i są bezpośrednio dostępne dla zwiedzających (albumy można na miejscu przeglądać).

Dowodów kobiecej twórczości artystycznej w lagrach nie brakuje, natomiast jej śladowa obecność w książce niemieckiego historyka sztuki pozostaje analogiem ogólnej sytuacji dotyczącej obozowego doświadczenia kobiet, zarówno jako wyobrażeń tkwiących w świadomości społecznej (a raczej ich deficytu), jak i badania tego zagadnienia, rozmaitych form utrwalania i popularyzacji. Niemalże nie wyłaniają się one spośród analogicznych reprezentacji męskości, tak dalece zadomowionej w zbiorowym imaginarium, że już symbolicznej w sposób generalny i wyłączający inne projekcje. To więzień-mężczyzna zuniwersalizował doświadczenie lagrowe i stał się osobową figuracją

6 Zob. J. Jaworska, „Nie wszystek umrę...”, dz. cyt., s. 103-104. Jej prace stanowią np. materiał ilustracyjny do polskiej edycji zbioru obozowych opowiadań włoskiej więźniarki Birkenau Liany Millu, zob. L. Millu, Dymy Birkenau, tłum. K. i E. Kabatcowie, Oświęcim 2007.

7 „Hiszpańska dotarła do Warszawy na przełomie lipca i sierpnia 1945 r. Przywiozła ze sobą kilkanaście rysunków. Tyle ocaliła z ponad czterystu, które wykonała w obozie”, M. Czarnecka, E. Kiedio, Zostały mi słowa miłości. Maria Hiszpańska-Neumann: życie i twórczość, Warszawa 2019, s. 110.

8 Po powstaniu warszawskim do Ravensbrück trafiła też międzywojenna graficzka i malarka Wiktoria Julia Goryńska, łącznika AK „Leti”, zmarła 29.03.1945, krótko przed ewakuacją, w najtrudniejszym okresie obozu, nasilonego chaosu, braku pożywienia i wzmożonych selekcji. 
obozu koncentracyjnego, męska postać przyodziana w pasiak partycypuje w większości społecznych wyobrażeń związanych z tym historycznym doświadczeniem. Ta niewspółmierność istnieje nie tylko jako odziedziczone po poprzednich pokoleniach status quo, ale i w obrębie bieżących działań społecznych, również w polu kultury humanistycznej, i wciąż „wybija”, najczęściej jako po prostu pominięcie. W Polsce nie mamy na przykład „szkoły” badania kobiecych lagrowych relacji, zaś zorientowane w tym kierunku badania światowe skupiają się, co zrozumiałe, na Holokauście9. (Nie poprawiają sytuacji, a wręcz przeciwnie, publikacje - ,potworki” przepoczwarzające temat w stereotyp tak dalece spełniający ideologiczne zapotrzebowania, że staje się on groteskowo nieczytelny $\left.{ }^{10}\right) .{ }^{11}$

W niniejszym artykule chcę zwrócić uwagę na obozową twórczość Jadwigi Simon-Pietkiewicz, malarki, litografki, rysowniczki szeroko uznanej już przed II wojną światową. Jej prace plastyczne powstałe w obozie koncentracyjnym Ravensbrück są zupełnie wyjątkowe nie tylko ze względu na ich walory artystyczne, specjalną wartość dokumentalną, ale i wielki potencjał przezwyciężania wspomnianej jednostronności.

W związku z ewakuacją więźniarek z Ravensbrück w kwietniu 1945 roku (spektakularna akcja szwedzkiego Czerwonego Krzyża) duża część tej lagrowej kolekcji trafiła do Szwecji i, co jest dosyć niespodziewane, nie pozostaje tam anonimowa. Svenskt konstnärslexikon (Leksykon szwedzkich artystów) prezentuje polską malarkę pośród grona twórców skandynawskich $^{12}$, a jej nazwisko pojawia się we współczesnych szwedzkich projektach. Prace Simon-Pietkiewicz można było niedawno, bo od maja do września 1919 roku, zobaczyć na wystawie organizowanej w sztokholmskim Tensta Konsthall (Centrum Sztuki Współczesnej), które eksponowało ponad

9 Tym cenniejsze pozostają w tym polu pojedyncze inicjatywy badawcze (np. Domu Spotkań z Historią) i prace (Nikliborc, Filipkowski) (wymieniam tylko przykładowe).

10 S. Winnik, Dziewczęta z Auschwitz. Glosy ocalonych kobiet, Warszawa 2018, 2019.

11 Dyskusję na ten temat prowadzi już od pewnego czasu Weronika Grzebalska (Płeć powstania warszawskiego); zob. też tejże: Od fatszywego uniwersalizmu do fetyszyzacji różnicy. Historia powstania warszawskiego i rewizjonistyczny „zwrot herstoryczny”, „Pamięć i Sprawiedliwość” 2015, nr 2, s. 139-158.

12 Svenskt konstnärslexikon, del V, sid. 151, Allhelms Förlag, Malmö, http:/libris.kb.se/bib/8390296 
czterdzieści oryginałów z kolekcji Malmö Konstmuseum (Muzeum Sztuki w Malmö $\left.{ }^{13}\right)$. Zorganizowana w Sztokholmie wystawa „Migration: Spår i en konstsamling” („Migracje: dzieła w kolekcji sztuki”) koncentrowała się na artystach emigracyjnych lub związanych z emigracją, albo emigracyjnymi motywami twórczości, tutaj - inaczej niż w albumie Jürgena Kaumköttera - przecięły się losy równocześnie prezentowanych obrazów Petera Weissa i Jadwigi Simon-Pietkiewicz ${ }^{14}$. (Na ekspozycji wyodrębniono wątek związany z rokiem 1945 i ewakuacją do Szwecji więźniów uwolnionych z niemieckich obozów koncentracyjnych; Muzeum w Malmö spełniło wówczas rolę pierwszego uchodźczego miejsca postoju, sale ekspozycyjne udostępniono dla zakwaterowania poobozowych „rozbitków”, wśród których znalazła się też artystka ${ }^{15}$ ). Jadwiga Simon-Pietkiewicz pojawiła się także w 2019 roku na organizowanej przez sztokholmskie Forum för levande historia (Forum żywej historii) wystawie „Not the End - Konstnärer tolkar Förintelsen” („Nie koniec” Artyści Interpretują Holokaust ${ }^{16}$ ). Jej prace występowały tam obok Mirosława Bałki, najbardziej chyba cenionego dzisiaj na świecie polskiego konceptualisty podejmującego temat Zagłady, wśród twórczości artystów ze Szwecji, Austrii i Izraela. Stała kolekcja wykonanych w obozie koncentracyjnym rysunków autorstwa Simon-Pietkiewicz znajduje się w sztokholmskim Moderna Museet (Muzeum Nowoczesnym ${ }^{17}$ ). Kilka

13 https://www.mutualart.com/Exhibition/Migration--Traces-in-an-Art-Collection/A9B5B03FB2EA9E65

14 W mediach podawano o artystce i jej pracach : „Brała udział w wielu wystawach w swoim rodzinnym kraju oraz w Paryżu i Nowym Jorku. W 1941 roku została aresztowana przez nazistów i trafiła do obozu koncentracyjnego w Ravensbrück. W 1945 roku uratowano ją w Malmö, tam trafiła do sanktuarium sztuki - Muzeum Sztuki w Malmö, kiedy zostało ono przekształcone w ośrodek dla uchodźców. Prace, które ofiarowała muzeum powstały w obozie. Powstały na „organizowanym" papierze i były narysowane kradzionymi kredkami i ołówkami, aby je ukryć zaszywała je w ubrania", zob. https://www.instagram.com/p/Bx94xSoiAm9/

15 Pod poniższymi linkami można zobaczyć listę szwedzkich miejsc zakwaterowania (obozów stałych i tymczasowych) również polskich byłych więźniów lagrów http://www.alvin-portal. org/alvin/attachment/document/alvin-record:147571/ATTACHMENT-0004.pdf, http://www.alvinportal.org/alvin/attachment/document/alvin-record:147572/ATTACHMENT-0002.pdf, dokumenty te są obecnie przechowywane w archiwum Biblioteki Uniwersyteckiej w Lund.

$16 \mathrm{https://www.levandehistoria.se/utstallningar/tidigare-utstallningar/not-end}$

17 W większości można je zobaczyć w dostępie online: https://www.europeana.eu/portal/pl/ record/91658/MM_objekt_213131.html?q=Ravensbr\%C3\%BCck+concentration+camp+ 
zostało przekazanych przez artystkę do Polskiego Instytutu Badawczego w Lund, prace te znajdują się obecnie w archiwum Biblioteki Uniwersyteckiej w Lund ${ }^{18}$.

We współczesnej polskiej refleksji historii sztuki oraz wystawiennictwa artystycznego Simon-Pietkiewicz niemal się nie pojawia ${ }^{19}$. Nie odnotowują jej nazwiska Polski stownik biograficzny ${ }^{20}$, ani Poczet artystów polskich $i$ w Polsce działajacych ${ }^{21}$. Najbogatszy i jedyny tak tematycznie rozbudowany materiał o Simon-Pietkiewicz oraz reprodukcje (słabej technicznie jakości) kilkudziesięciu jej prac zawiera, przywoływane już tutaj, kompendium autorstwa Janiny Jaworskiej „Nie wszystek umrę...”. Twórczość plastyczna Polaków w hitlerowskich więzieniach i obozach koncentracyjnych 1939-194522. Liczne oryginały prezentowanych tam rysunków i akwarel, wówczas będące w posiadaniu Klubu Byłych Więźniarek Obozu Koncentracyjnego Ravensbrück, dziś znajdują się w kolekcji warszawskiego Muzeum Niepodległości, zaś szkicownik zawierający ponad pięćdziesiąt prac, głównie portretów współwięźniarek, ma w swoich zbiorach magazyn ikonografii warszawskiej Biblioteki Narodowej23. Te zbiory oraz kolekcje ze Szwecji tworzą w sumie galerię ponad trzystu (sic!) przedstawień więźniarek z Ravensbrück.

Jadwiga Simon-Pietkiewicz urodziła się..., no właśnie, źródła polskie podają tu datę 1906, natomiast szwedzkie rok 1909. Sama artystka będąc już w Szwecji,

18 http://www.alvin-portal.org/alvin/resultList.jsf?aq

19 W październiku 2019 roku artystka była drugoplanową bohaterką, obok Mai Berezowskiej, referatu Figury oporu: Maja Berezowska i artystki z Ravensbrück" wygłoszonego przez Agatę Pietrasik na ogólnopolskiej sesji naukowej „Sztuka przeciw wojnie i faszyzmowi w XX i XXI wieku” organizowanej przez Muzeum Sztuki Nowoczesnej w Warszawie, https://artmuseum.pl/pl/doc/video-agata-pietrasik-figury-oporu

20 Z kolei Stownik artystów polskich został tymczasem doprowadzony do dziesiątego tomu i hasła rozpoczynającego się na 'Slę'.

21 Poczet artystów polskich $i$ w Polsce działających, red. K. Lewicka, B. Osińska, Warszawa 1996.

22 Jest to pod informacyjnym względem obfite, choć i wybiórcze, źródło, nie prezentuje np. artystów i artystek, którzy wyemigrowali, albo musieli opuścić Polskę w 1968 z artystek pomija Halinę Ołomucką [1972 Izrael via Paryż (1957)].

23 J. Simon-Pietkiewicz, Szkicownik z portretami więźniarek z Ravensbruck (tytuł nadany przez osobę katalogująca), 1944; AFRys. 144/I. 
jako rok swego urodzenia podaje konsekwentnie $1909^{24}$. Prześledźmy jej życiorys za przygotowaną przez samą artystkę krótką autobiografią przeznaczoną dla skandynawskiego odbiorcy - biogram ten dołączony do katalogu wystawy obozowych prac autorstwa Simon-Pietkiewicz ${ }^{25}$, inaugurowanej już w maju 1945 roku, a więc krótko po dotarciu więźniarek na półwysep skandynawski, został przetłumaczony na język szwedzki przez współinicjatora tej nadzwyczajnej ekspozycji Zygmunta Łakocińskiego ${ }^{26}$.

Urodziłam się w Warszawie 6 czerwca 1909 r. Po ukończeniu szkoły kształciłam się przez rok w szkole Krzyżanowskich w zakresie rysunku i malarstwa pod kierownictwem profesora Adama Rychłowskiego. Po zdaniu egzaminów w 1927 r. dostałam się do Warszawskiej Akademii Sztuk Pięknych, gdzie uczyłam się malarstwa sztalugowego i monumentalnego jako przedmiotu dodatkowego w pracowni profesora Tadeusza Pruszkowskiego. Miałam także styczność z techniką tempery i fresku. Byłam bardzo zainteresowana malarstwem ściennym i marzyłam, żeby się tym zająć, ale moje życie potoczyło się zupełnie inaczej. Technikę ścienną zamieniłam na technikę tempery, tworząc na drewnianym podłożu, eksperymentując z różnymi obróbkami powierzchniowymi. Malowałam portrety i tworzyłam kompozycje figur wtopione w krajobrazy albo wnętrza. Moją techniką stał się szkic, i kiedy malowałam krajobrazy akwarelą, szkicowałam pierwotnie tuszem, co zwiększało wrażenie delikatności. Nie wierzę, żeby te dzieła przetrwały, spaliły się we wrześniu 1939 r. podczas oblężenia Warszawy. Podczas pożaru zniszczyły się trzy z moich większych obrazów w Instytucie Sztuk Pięknych w Warszawie. Zawsze

24 Zdarzało się, że w związku z wojennym zniszczeniem wielu archiwów, do tworzonych po 1945 roku dokumentów podawano zmienione dane (Maja Berezowska, zmieniła datę swojego urodzenia i ujęła sobie kilka lat), nie wiadomo, ale wiele na to wskazuje, czy to również przypadek Simon-Pietkiewicz.

25 Według popularnego źródła szwedzkiego (Wikipedia), wystawiano wówczas również prace Mai Berezowskiej i niezidentyfikowanej przeze mnie artystki (Kusmievkowa), https://sv.wikipedia. org/wiki/Jadwiga_Simon, (nawiasem mówiąc Simon-Pietkiewicz nie poświęcono hasła w polskiej edycji Wikipedii). Nie udało mi się znaleźć potwierdzenia tej informacji.

26 Zygmunt Łakociński to ważna postać w kontekście losów polskich byłych więźniarek, w okresie wojny i zaraz po jej zakończeniu był on polskim lektorem języka szwedzkiego w Lund. Zatrudniony przez Szwedów do językowej pomocy podczas ewakuacji Polek zorientował się szybko, że w ramach systemowo prowadzonej i archiwizowanej pracy należy zebrać relacje byłych więźniarek. W tym celu utworzono Polski Instytut Źródłowy w Lund, który zaraz po przybyciu tam polskich byłych więźniarek rozpoczął pozyskiwanie i gromadzenie nie tylko ich relacji, ale i dokumentów i pamiątek. 
miałam pecha z pożarami... W 1930 r. wyszłam za mąż za zdolnego rzeźbiarza Kazimierza Pietkiewicza. Od tego czasu pracowałam w domu. Mieszkaliśmy na wsi poza Warszawą i tam zaczęłam robić szkice krajobrazów, w szczególności interesowały mnie kwitnące wiosenne drzewa i jesienne liście. W 1931 r. założyliśmy razem z kilkoma kolegami zgromadzenie o nazwie „Loża Wolnomalarska". Od roku 1932 brałam udział w wielu wystawach zbiorowych m.in. w 12 wystawach w Warszawie. Moje dzieła były pokazywane na zarówno polskich, jak i zagranicznych wystawach sztuki m.in. w Amsterdamie (1933), Brukseli (1935), na wystawie światowej w Paryżu (1936, 1937), Kopenhadze, Londynie i Nowym Jorku (1939, wystawa światowa). W 1939 r. wybuchła wojna. Zdecydowałam się, żeby nie wystawiać moich dzieł w czasie niemieckiej okupacji. Tak się złożyło, że zostałam aresztowana 15 lutego 1941 r. W czasie przeszukania znaleziono w moim mieszkaniu kompromitujące materiały pochodzące z polskiego ruchu oporu. Przez 8 miesięcy siedziałam w więzieniu na „Pawiaku” w Warszawie, to dobrze znane więzienie dla wielu generacji Polaków. We wrześniu 1941 r. przewieziono mnie do Ravensbrück w Niemczech. Pojechałam pierwszym dużym transportem z „Pawiaka”. W skład transportu wchodziło 275 więźniów z Warszawy, a potem dołączono 145 więźniów z Lublina. Transporty te nazwano "Sondertransport" i były rzeczywiście specjalne. W ciągu półtora roku poddano eksperymentalnym operacjom 70 kobiet z transportu lubelskiego i rozstrzelano 15 z nich i 5 kobiet z Warszawy. Przez cały czas rysowałam. 8 szkicowników [bloki rysunkowe] udało mi się przesłać z „Pawiaka” mojemu brata. W roku 1943 nadarzyła się okazja, żeby przesłać do Polski część rysunków stworzonych w Ravensbrück. Między tymi rysunkami znajdowała się część portretów operowanych i rozstrzelanych. Zbiór akwarel i rysunków, które obecnie zostały wyeksponowane, stanowią 1/4 tego, co stworzyłam w ostatnim czasie w Ravensbrück. Resztę materiałów rozdzielono między uchodźców, z których przynajmniej jeden dotarł już do Szwecji27.

27 Szwedzkojęzyczny katalog wystawy Simon-Pietkiewicz z 1945 roku można znaleźć w zbiorach Biblioteki Uniwersyteckiej w Lund, https://www.alvin-portal.org/alvin/attachment/ document/alvin-record:101874/ATTACHMENT-0006.pdf http://www.alvin-portal.org/alvin/imageViewer.jsf?dsId=ATTACHMENT-0001\&pid=alvin-record\%3A271876\&dswid=-9842. Polski oryginał zawartej tutaj krótkiej autobiografii Jadwigi Simon-Pietkiewicz nie zachował się, na potrzeby artykułu została ona przetłumaczona, na powrót na język polski, z języka szwedzkiego przez Tomasza Leśniaka pracującego obecnie w Bibliotece Uniwersyteckiej w Lund, któremu - za bezinteresowną pomoc - składam tutaj podziękowanie. 
Jak możemy przeczytać na stronie internetowej lundańskiej Biblioteki Uniwersyteckiej „Wystawa sztuki w Galerii Svartbrödraklostret w Lund zorganizowana przez dra Zygmunta Łakocińskiego była sukcesem komercyjnym. Rysunki Jadwigi wyprzedano, gdy tylko zostały ujawnione"28. Ekspozycję komentował nie tylko szwedzki, do dzisiaj wychodzący „Expressen”, ale i „Narodowiec”, największe polskie czasopismo wydawane we Francji (numer z czerwca 1945): „W mieście Lund, w południowej Szwecji, dokoła którego grupują się obozy 6.500 Polek zwolnionych z Ravensbrück i z innych obozów niemieckich, otwarto wystawę akwareli J. Simon-Pietkiewicz, lat 35., która przebywała w Ravensbrück od 1941 roku. Obrazy przedstawiaj życie w obozie. Dziennik »Expressen« pisze, że obrazy p. Simon-Pietkiewicz są nie tylko dziełami sztuki, ale także dokumentami przedstawiającymi tę ponurą rzeczywistość, w której żyły mieszkanki niemieckich obozów koncentracyjnych"29.

Wspomniane kompendium Nie wszystek umrę... podaje, że obozowe losy Simon-Pietkiewicz zostały spisane przez nią samą, lecz relacji tej nie opublikowano ${ }^{30}$. Cytowany we fragmentach w książce Janiny Jaworskiej materiał wspomnieniowy w dużej mierze odpowiada protokołowi zeznania malarki złożonemu w lutym 1946 roku w Polskim Instytucie Źródłowym Lund ${ }^{31}$. (Powstały jesienią 1946 roku Instytut zgromadził ponad pół tysiąca relacji byłych więźniarek obozów koncentracyjnych ${ }^{32}$ ). W pierwszym ze źródeł informacje dotyczące przedwojennego, jak i skandynawskiego etapu biografii artystki po-

28 https://www.alvin-portal.org/alvin/view.jsf?dswid=-2859\&searchType=EXTENDE$\mathrm{D} \&$ query $=\mathrm{Jadwiga}+$ Simon\&aq $=\% 5 \mathrm{~B} \% 5 \mathrm{~B} \% 7 \mathrm{~B} \% 22 \mathrm{~A} \_\mathrm{FQ} \% 22 \% 3 \mathrm{~A} \% 22 \mathrm{Jadwiga}+$ Simo$\mathrm{n} \% 22 \% 7 \mathrm{D} \% 5 \mathrm{D} \% 5 \mathrm{D} \& \mathrm{aqe}=\% 5 \mathrm{~B} \% 5 \mathrm{D} \& \mathrm{af}=\% 5 \mathrm{~B} \% 5 \mathrm{D} \&$ pid=alvin-record $\% 3 \mathrm{~A} 271876 \& \mathrm{c}=3 \#$ alvinrecord $\% 3 \mathrm{~A} 271876$

29 Nota Echa tragedii Polek w Ravensbrück, „Narodowiec”, 1945, nr 133, s. 2, https:// argonnaute.parisnanterre.fr/medias/customer_3/periodique/immi_pol_lotmz1_pdf/BDIC_ GFP_2929_1945_133.pdf

30 Janina Jaworska, ,Nie wszystek umrę...”..., s. 108.

31 https://www.alvin-portal.org/alvin/view.jsf?dswid=-2859\&searchType=EXTENDED\&query $=\mathrm{Jadwiga}+$ Simon\&aq $=\% 5 \mathrm{~B} \% 5 \mathrm{~B} \% 7 \mathrm{~B} \% 22 \mathrm{~A} \_\mathrm{FQ} \% 22 \% 3 \mathrm{~A} \% 22 \mathrm{Jadwiga}+$ Simo$\mathrm{n} \% 22 \% 7 \mathrm{D} \% 5 \mathrm{D} \% 5 \mathrm{D} \& \mathrm{aqe}=\% 5 \mathrm{~B} \% 5 \mathrm{D} \& \mathrm{af}=\% 5 \mathrm{~B} \% 5 \mathrm{D} \& \mathrm{pid}=$ alvin-record $\% 3 \mathrm{~A} 101874 \& \mathrm{c}=1 \#$ alvinrecord $\% 3 \mathrm{~A} 101874$

32 Zob. E. S. Kruszewski, Instytut Źródłowy w Lund (1939-1972): zarys historii i dorobek, Londyn - Kopenhaga 2001; Jan Draus, Nauka polska na emigracji 1945-1990, w: Historia nauki polskiej, t. 10, 1944-1989. Cz. 2, Instytucje, red. L. Zasztowt i J. Schiller-Walicka, Warszawa 2015, s. 485-682. 
dano dosyć oszczędnie, co jest do zrozumienia, wziąwszy pod uwagę, że jest to pozycja z połowy lat siedemdziesiątych minionego wieku. Z kolei sprawozdanie Simon-Pietkiewicz z Lund jako najważniejsze uwzględnia doświadczenie obozowe widziane przez pryzmat ogólnych warunków w lagrze i relacjonuje, oprócz jej własnych, losy innych więźniarek, również „króliczek”.

Nie sposób, chociaż skrótowo, nie przedstawić tutaj (na podstawie tych dwu źródeł) lagrowej biografii Simon-Pietkiewicz; stanowi ona nie tylko jeszcze jedną wojenną mikrohistorię kobiecą, ale i somatyczne curriculum vitae o niebywałym nasyceniu dramatyzmem. Owa, nazwijmy to, biografia obozowego ciała zadecydowała o charakterze prowadzonej twórczości plastycznej (o tym dalej). Artystka dzieli prawie czteroletni okres obozowy na kolejne siedem etapów, odpowiadają one nie tylko chronologii zewnętrznych zdarzeń, ale samopoczuciu psychicznemu oraz stanowi jej coraz to bardziej pogarszającego się zdrowia, pogłębiającej się ułomności fizycznej i ograniczeniom jakie narzuciła.

Etap 1: końcówka 1941 roku, to trzymiesięczna praca przy wytwórstwie zabawek w warsztacie artystycznym Kunstgewerbe, zaś po przekształceniu warsztatu i „redukcji” etatów kilkudniowa praca przy piasku, a potem, w komandzie zewnętrznym, przy wyrobie drewnianych obcasów.

Etap 2: rok 1942, nocna praca w futrzarni, która mimo dramatycznych warunków umożliwiała rysowanie. Już tutaj widoczne jest, że więźniarkę interesowało artystyczne studium portretowe: „Wolałam pracę nocną od dziennej, była bardziej wyczerpująca, ale nadzór nie był tak ścisły i udawało mi się trochę rysować. Wymykałam się do toalety, gdzie miałam rodzaj atelier. Ciekawe było rysowanie Cyganek, fantastycznie okutanych w strzępy futer, lub śmiertelnie zmęczonych kobiet, które pod pretekstem potrzeby szły do ubikacji, padały na ziemię i zasypiały bodaj na chwilę"33. Artystka powie też, że nigdy w obozie nie czuła się tak zdruzgotana i zniewolona, jak w tym, trwającym jedenaście miesięcy okresie. Wówczas już zaczęła ciężko chorować. Mający źródło w przemarznięciach stan zapalny utrwalił się jako głębokie zapalenie rdzenia kręgowego i czasowy paraliż. Chorobę pogłębiła dwukrotnie nałożona na malarkę kara bunkra (zimne, zaciemnione więzienie z ograniczo- 
nym do minimum pożywieniem): za rysowanie w czasie pracy oraz nałożenie niedozwolonej kamizelki, którą uszyła ze skrawków futer.

Etap 3: listopad 1942 - luty 1944 to okres związanego z chorobą pozostawania w bloku oraz praca w kilku różnych komandach: leśnym, tragarek kamieni, oczyszczania latryn, magazynowym, sztrykerynek. To również okres rekonwalescencji po przypadkowym zranieniu w dłoń, które przeszło w ciężkie owrzodzenia. W całym tym okresie Simon-Pietkiewicz w miarę możliwości rysowała, została też zauważona przez współwięźniarki, również funkcyjne, jako artystka i tworzyła portrety na zamówienie. Jak później powie: „Rysunki z tego okresu udało mi się przesłać do Polski jesienią 1943 r. [...] Rysunki te dotarły do Polski i spłonęły w Warszawie w czasie powstania" 34 .

Etap 4: od wiosny do jesieni 1944 był czasem narastającej choroby owrzodzenia i związane z nimi stany zapalne rozszerzały się, konieczne stały się operacje na rewirze, pojawiały się też kolejne ataki paraliżu. „Od wiosny 1944 r. chodziła już o lasce. W sierpniu złamała nogę. Cały rok 1944 to wędrówka między blokami a rewirem"35 - relacjonowała Janina Jaworska (warto pamiętać, ze mowa o osobie trzydziestokilkuletniej.)

Etap 5: jesienią 1944 roku decydujące okazało się wsparcie współwięźniarek z grupy tzw. wrześniówek, czyli z transportu specjalnego z 1942 roku (numery tzw. siedmiotysięczne); trwało ono również podczas kolejnej, szóstej fazy.

Etap 6: od jesieni 1944 do marca 1945 roku, artystka opatruje komentarzem: „Przyjdą dni, gdy żywi zaczną zazdrościć umarłym”36. Wówczas zaczyna się dla Ravensbrück szczyt najgorszego okresu obozu, masowego zabijania, drastycznego głodu, fatalnych warunków. Simon-Pietkiewicz ciągle choruje i stale jest poważnie zagrożona selekcją, chroni się przed nią dzięki fikcyjnemu, zorganizowanemu przez koleżanki zaświadczeniu umożliwiającemu pozostawanie w bloku (pacjentki rewiru regularnie wybierano do zagazowania).

Etap 7: marzec - kwiecień 1945 roku to dosłownie ucieczki i ukrywanie się przed śmiercią (podczas selekcji artystkę „wścielano” w zasłane łóżko). W połowie kwietnia 1945 w obozie pojawiły się szwedzkie autokary i rozpoczęto ewakuację pierwszych grup więźniarek.

34 Tamże, s. 91.

35 Tamże, s. 92.

36 Tamże. 
W Szwecji Jadwiga Simon-Pietkiewicz przebywała do połowy 1946 roku. Jak większość artystów i artystek powracających do kraju próbowała odnaleźć się w nowej, wkrótce już socrealistycznej rzeczywistości i w ramach uprawianej sztuki wcielać w życie „rozwiązania pośrednie”. Z tego okresu pochodzą akwaforty przedstawiające tkaczki z fabryki Milanówek, prace prezentujące hutników oraz portrety w stylu Dziewczyna z ZMP, ale i „zwykłe”, niezaangażowane impresje ${ }^{37}$. W roku 1954 Związek Polskich Artystów Plastyków zorganizował wystawę na dwudziestolecie twórczości malarki. Wobec jej ciągle pogarszającego się, zrujnowanego obozem zdrowia było to swoiste finis coronat opus.

W pierwszych dniach listopada 1955 roku „Życie Warszawy” zamieściło nekrolog:

JADWIGA SIMON-PIETKIEWICZ członek Związku Polskich Artystów Plastyków, odznaczona Złotym Krzyżem Zasługi i Medalem Dziesięciolecia, zmarła dnia 31 października 1955 roku. Nabożeństwo żałobne odbędzie się w kościele św. Karola Borom., nr. Powązkach, dnia 4 bm. (piątek) o godz. 11.40, po którym nastąpi wyprowadzenie zwłok na cmentarz miejscowy.

Obozowa twórczość Simon-Pietkiewicz była kontynuacją aktywności artystycznej prowadzonej przez nią na tzw. Serbii, kobiecym oddziale Pawiaka; tam powstawały pierwsze sceny więzienne - wykonane ołówkiem, kredkami oraz akwarelami na skrawkach dostępnego papieru (najczęściej na fragmentach opakowań przekazywanych więźniarkom paczek). Techniki nie mogły być wyszukane i czasochłonne, toteż lagrowe prace to najczęściej rysunki, czasem bardziej dopracowane, kiedy indziej tylko nakreślone kilkunastoma szkicowymi kreskami, a jednak zwykle dające wyobrażenie o gdzie indziej nie przedstawionych szczegółach obozowej egzystencji kobiet. Cechą tej sztuki jest mistrzostwo uchwycenia portretowanej cielesności i zawartej w niej emocji, przy, najczęściej, zastosowaniu niewymuszonej, wydawałoby się niedbałej kreski. (Ta charakterystyka nawet w niewielkim stopniu nie wyczerpuje bogactwa niuansów i finezji przedstawiania fizycznej i psychoemocjonalnej rzeczywistości kobiecego społeczeństwa obozu.) Artystka rysowała

37 https://zacheta.art.pl/public/upload/mediateka/pdf/57fcf2f3d450c.pdf 
„zorganizowanymi” ołówkami, kredkami (najczęściej niebieskimi), piórem, a także malowała pędzlem akwarele. Zagadką (tymczasową?) pozostaje sposób, za pomocą którego zdobywała farby i pędzle, ale jedno z używanych przez nią malarskich narzędzi można zobaczyć w Muzeum Szwedzkiej Rady Dziedzictwa Narodowego, w kolekcji dotyczącej Ravensbrück. Jest to dosyć osobliwy pędzelek wykonany z włosia pędzla do golenia, przymocowanego do skręconego, sztywnego sznurka (zaszyty w pasiaku, można było nosić $\mathrm{z}$ sobą) $)^{38}$.

Lagrowe prace Simon-Pietkiewicz mają niewielki rozmiar (najczęściej kilkanaście centymetrów kwadratowych), wykonano je na papierze pakowym, czasem na marginesie gazet niemieckich (wówczas i rewers może zderzać nas z historycznym konkretem, bo na odwrocie czytamy na przykład nekrologi żołnierzy SS lub artykuły z ówczesnej niemieckiej prasy) lub fragmentach formularzy obozowej administracji. Rysunki prawie zawsze są datowane, sygnowane pierwszymi literami imienia i obu nazwisk autorki, najczęściej też zawierają informację kogo przedstawiono, a nawet jaki los stał się tej osoby udziałem (na przykład Strikerinka. „Poszła do jugendlagru do komina”, 1944), przy tym często wskazują miejsce (na przykład rewir), albo sytuację (na przykład śpi, odpoczywa, itp.). Już tylko te elementy przesądzają o ich bezcennej wartości historycznej, ale właściwie każdy z pozostałych, również ściśle fizycznych ich aspektów (technika wykonania, materiał, rozmiar) ma szczególną wartość dokumentu i stanowi osobną narrację o warunkach ich powstania. Tylko domyślać się możemy, ile pragmatycznej pomysłowości i „organizacji” składało się na możliwość wykonania rysunków, a jeszcze bardziej akwarel, przechowania tak delikatnej materii (na przykład cienka bibuła) i wyekspediowania jej poza obóz. Niepozorny format i wizualna skromność pozostają tu znacząco niewspółmierne do wagi źródłowej.

Dokumentarność tych powstałych w obozie koncentracyjnym przedstawień ma też inny, nietypowy charakter. Odtwarzają one fakty historyczne, ale nie takie, których najłatwiej można by się stamtąd spodziewać, nie prezentują scen niemieckiego okrucieństwa, nie utrwalają też najbardziej drastycznych stron lagrowej egzystencji (choć tu pewnie dałoby się polemizować). Bezpośredniość ujęcia Simon-Pietkiewicz nakierowana jest na tę warstwę doświad- 
czenia, która zazwyczaj skrywa się za skrajnymi, pierwszoplanowymi, ale i najbardziej wyeksploatowanymi tematami. Jak bezcenne zdjęcia (realizm artystki bywa fotograficzny, kiedy indziej zaś szkicowo-poglądowy), jej prace otwierają przed nami miejsca, które, pod karą śmierci, strzeżone były zakazem wstępu dla postronnych i w których nie możemy się znaleźć, bo już ich nie ma. Dzięki tym „fotografiom” wchodzimy na teren obozu, pomiędzy bloki, do sztub i stajemy się naocznymi świadkami kobiecego lagru, choć należałoby to raczej określić - świadkami życia kobiet w lagrze (dalej powrócę do tej, skądinąd ważnej tutaj, kwestii podmiotowości).

Użyłam ,perypatetycznej” metafory, bo oddaje ona perspektywę patrzącego, jakby przechodzącego przed, obok, za plecami przedstawionych, zajętych pracą, zwykłymi lagrowymi czynnościami, a czasem samym (prze) trwaniem kobiet. (To uczucie bezpośredniej bliskości i znalezienia się tuż obok portretowanych więźniarek jest dojmujące i owo złudzenie fizycznej obecności też składa się na somatyczność jako specyficzny charyzmat obozowych prac Simon-Pietkiewicz.) O takiej, nieco voyeurystycznej optyce zadecydowała tragiczna „cielesna biografia” samej autorki. Jej długotrwała choroba, unieruchomienie, możliwość przebywania w ciągu dnia w baraku i wielomiesięczne leczenia na rewirze, chociaż związane z ciągłym zagrożeniem selekcją, dawały trochę niezagospodarowanego czasu i stwarzały okazję do kontemplacyjnego śledzenia otoczenia. Wzmożone przez dolegliwości odczuwanie własnego ciała i borykanie się z jego niemocą skierowały uwagę i artystyczną emocję na somatyczność samą w sobie, w tamtych okolicznościach najczęściej udręczoną i bezbronną, albo w jakiś sposób charakterystyczną. Z pewnością decydująca była również „dostępność” obiektów, ich znalezienie się w polu widzenia, które zostało ograniczone doraźną lokalizacją i unieruchomieniem. Rysunki wskazują na przykład czasem na perspektywę wertykalną, tak jakby obserwatorka została zawieszona nad „modelką”, domyślać się wtedy możemy usytuowania malarki „piętro wyżej”, na górnej pryczy baraku mieszkalnego czy rewirowego. Ten realizm, który przez swoją bezpośredniość staje się dokumentalizmem, wyłącza właściwie pojawiającą się w odniesieniu do doświadczenia obozów i Zagłady refleksję o idiomatycznych funkcjach sztuki, zaś wyzwaniem, przed którym staje współczesny „,czytelnik” rysunków Simon-Pietkiewicz, jest nie tyle pobudzana wyobraźnią interpretacja, ile wnikliwa „lektura” podbudowana historyczną wiedzą. 
Wówczas pieczołowicie odnotowane przez malarkę szczegóły stają się narracją wskazującą na konkretne parametry kobiecego doświadczenia obozów koncentracyjnych.

Tutaj przybliżę tylko kilka artystycznych odsłon, w dosłownym tego znaczeniu, bo dzięki nim możemy przyglądać się typowym dla lagru gestom czy ułożeniom ciała, w normalnych warunkach zarezerwowanym dla przestrzeni o bardziej osobistym charakterze.

Jako charakterystyczną pozycję ciała więźniarek odpoczywających w baraku, a zarazem ich pozycję psychiczną, jeśli tak można powiedzieć, malarka uchwyci powtarzany gest podpierania czoła połączony z zakrywaniem oczu. Wspominając później powie: ,„[...] szkicuję grupy więźniarek. Drzemiące lub siedzące przy stołach. Jesteśmy przecież stale niewyspane. Charakterystyczny ruch w lagrze to podpieranie ręką głowy, jakby dla zasłonięcia się przed otaczającą rzeczywistością"39. Toteż w obrazach Trzy siedzace kobiety podpierające głowy (1943) albo Portret $d$ wóch kobiet (1943) i wielu innych możemy zobaczyć wiele mówiące ułożenie kobiecych ciał, jakby zawieszonych na opartych o stół blokowej sztuby łokciach, z przysłoniętą dłońmi twarzą albo uchwyconą w nie głową. Poprzez tę pozycję manifestuje się codzienne udręczenie, ale też potrzeba samotności zaspokajanej w tak mocno ograniczony sposób. Narastające zatłoczenie Ravensbrück i brak szans za zachowanie jakiejkolwiek intymności kazały szukać jej namiastek za złożonymi przed oczyma palcami rąk. Podobne ułożenia ciał zostały też utrwalone jako charakterystyczne dla odnotowanego w wielu lagrowych literackich relacjach, ważnego, częstokroć wstrząsającego momentu odczytywania korespondencji od najbliższych. Sygnały z wolności miały w obozie niemierzalną wagę i kolosalnie emocjonalne znaczenie. Na rysunku Jadwigi Simon-Pietkiewicz z 1944 roku Czytanie listów zobaczymy, że w grupie kobiet zebranych wokół osoby czytającej na głos (pewnie sztuby jadalnianej) kilka $\mathrm{z}$ nich przyjęło pozycję odzwierciedlającą trudność przeżywania tego momentu i dramatyczne poszukiwanie samotności - bryła ich ciał pozostaje zamknięta, obramowana łokciami i ramionami, głowa schowana między dłońmi, bądź czoło podparte ręką, zasłonięta twarz. Te właśnie postaci, nie zaś czytająca, są kontrapunktem relacjonującym napiętą emocjonalność utrwalonej sceny. 
W Moderna Museet znajduje się oryginał rysunku Spanie w bloku, datowany na koniec grudnia 1944 roku. To czas krańcowego przepełnienia lagru, Ravensbrück wówczas już od kilkunastu miesięcy pełnił rolę centrali tranzytowej w ewakuacji więźniarek z obozów „,zagrożonych” wyzwoleniem. „Ciasnota na bloku była potworna, a spanie po 2 na wąskich łóżkach nie zabijało od razu, lecz było torturą przyprawiającą o stopniową utratę sił"40 - to relacja więźniarki Marii Wysznackiej z kwietnia 1944 roku. Jeden z rysunków Simon-Pietkiewicz oddaje charakterystyczny dla tego okresu sposób spania „na sardynki” (tak określały go więźniarki), w którym głowa jednej z nich znajdowała się na wysokości nóg drugiej. Praca, jak informuje umieszczony na niej dopisek autorki, powstała w bloku chorych, ale domyślać się tego można i na podstawie samego obrazu - pod koniec 1944 roku w innych blokach lagru nie było już wówczas takiego „komfortu” i na jednej pryczy musiały się zmieścić więcej niż dwie więźniarki ${ }^{41}$. Odpowiadającą temu stanowi „sytuację cielesną” kobiet charakteryzują sztywne, wymuszone ciasnotą pozy, trudno nie zastanowić się nad pozycją głowy jednej ze śpiących, odwróconą od sąsiadki, nienaturalnie skręconą w bok, na wolną stronę pryczy.

Spójrzmy i na inny rysunek leżącej, to Portret Janiny Piątek (1944), przedstawiający spoczywającą w łóżku kobietę. Ta praca także powstała w obozowym rewirze. Widzimy tylko odkrytą twarz z zamkniętymi oczami, rozsypane na poduszce krótkie włosy i kikut zgiętej, zabandażowanej ręki bez dłoni, reszta pozostaje zakryta kocem. Za tym obrazem stoi historia jego bohaterki, którą malarka relacjonuje w zeznaniu z Lund:

Tragiczną postacią była Janina Piątek z ewakuowanej Warszawy. Wywieźli ją do fabryki amunicji Meuselwitz koło Lipska, gdzie w czasie bombardowania straciła prawą rękę do połowy przedramienia i zraniono ją w piętę. Na skutek złej pielęgnacji po 2 około miesiącach amputowano jej nogę powyżej kolana. Później na skutek złego opatrunku groziła jej gangrena. Leżała pode mną na łóżku. U lewej

40 M. Wysznacka, Bestie i ludzie. (Ravensbrück-Szwecja). Wspomnienia i wrażenia, Włocławek 1947, s. 15.

41 „Spanie było koszmarem. Na dwóch pryczach musiało się pomieścić 5-6 więźniarek. Większość siedziała przez całą noc, bo w tych warunkach spanie na pryczach pierwszego i drugiego piętra było niemożliwością", Muzulman wraca do domu i inne pamiętniki więźniów hitlerowskich obozów koncentracyjnych, oprac. S. Nowakowski, Kraków 1985, s. 64. 
ręki brakowało jej trzech palców, straciła je w 1939. Kiedy szczęśliwie uniknęła gangreny, w marcu wywieźli ją do komina, kiedy już była prawie zdrowa ${ }^{42}$.

Artystce udało się wyrazić bezwład i nieme cierpienie zrujnowanego ciała, Portret Janiny Piątek mógłby stanowić ikonę losów licznych więźniarek okaleczonych podczas niewolniczej pracy w niemieckich fabrykach zbrojeniowych.

Inny zupełnie, choć też utrwalający postacie okaleczonych kobiet, jest wykonany ołówkiem Portret Niny Iwańskiej i Bogny Bobińskiej z 1943 roku. To dwie z ponad siedemdziesięciu ,króliczek”, kobiet, które w 1942 i 1943 roku poddano eksperymentom pseudomedycznym, operując ich nogi. W rysunku Simon-Pietkiewicz otrzymujemy dość niespodziewany wizerunek - króliczki wygrzewają na słońcu pooperacyjne rany, grube pończochy są opuszczone do kostek, kolana odsłonięte, twarze z opuszczonymi powiekami wystawione do słońca. To leczenie ran, ale i obraz zachowanej witalności, każącej w wilgotnym i chłodnym klimacie meklemburskiej doliny szukać ozdrowieńczego ciepła.

Warto zwrócić uwagę na rysunek wykonany prawdopodobnie w rewirze, datowany 3.XI.1944, podpisany Madame Bergeret, Francuzka, 9 godzin przed śmiercią. Widoczna jest tylko twarz leżącej na wznak więźniarki - wyostrzony nos, zapadnięte rysy, brak mięśni pod skórą, podkrążone, półprzymknięte, nieobecne oczy. Włosy sterczą sztywne nad czołem, ich zmierzwione końce wystają na linii szczęki spod przyciśniętej do głowy poduszki, palce dłoni wystają ponad kocem, bezradnie dotykając szyi. To zupełnie rzadki portret ciężko chorej, w zasadzie umierającej kobiety.

Podobnie niespotykane są rysunki, które można pogrupować w cykle „mycie” oraz ,siedzenie na kuble (kiblu)”, wszystkie prezentują kobiety w naturalnych dla tych czynności pozach, nie stronią przy tym od eksponowania groteskowych, pokracznych wręcz pozycji ciała i oszpecającego zniekształcenia, czy wychudzenia. Pozostają zupełnie dalekie od jakiejkolwiek estetycznej stylizacji i uszlachetniającej schematyzacji. Widać żałosną brzydotę zabiedzonych ciał, czasem monstrualną, daleką od wyglądu fizjologicznej normalności tych zwykłych spraw.

42 http://www.alvin-portal.org/alvin/imageViewer.jsf?dsId=ATTACHMENT-0001\&pid=alvin-record\%3A101874\&dswid=-6222, rozwijam tu liczne skróty obecne w oryginale relacji (typu ,ewak. Warsz.” - ewakuowanej Warszawy). 
Prace grupują się też w galerie kobiecych obozowych zajęć: sztrikerinki (sztrykerynki), czyli więźniarki-cerowaczki lub szyjące (studium skupionych twarzy, z często ściągniętym czołem, przymrużonymi oczami), fryzur (warkoczyków związanych tasiemkami, szorstkich nierówno przyciętych jeży, pięknych, wbrew obozowym warunkom, pukli i koków), odzieży.

Zupełnym ewenementem są akwarele dające za pomocą barwnej plamy odzwierciedlenie wyniszczenia ciał, chorób i urazów skóry, zaczerwienienia wywołanego rozgorączkowaniem. Efekt takiego bezpośredniego przedstawienia jest zupełnie wstrząsający, realistyczny aż do zaniepokojenia widza.

Obozowa twórczość Simon-Pietkiewicz to rodzaj rysunkowej monografii o losach kobiecego ciała, uchwyconego z perspektywy jednego z obozowych centrów jego niedoli - pryczy rewiru, albo zwykłego baraku mieszkalnego. Obrazy te stanowią jakby serię somatycznych epizodów z Ravensbrück, fotoreportaż o ciałach zajętych codziennym lagrowym bytowaniem, w „barakowych" pozycjach, siedzące, leżące, myjące się, w trakcie jedzenia, snu, pracy, wypróżniania się, chorujące, okaleczone, wychudzone, nagie, ubrane. Dzięki tym rysunkom zyskujemy szansę na doprecyzowanie uwagi i przeniesienie jej z doświadczenia obozu jako złożonego i wieloaspektowego na kobiecy podmiot cielesny (,podmiot mówiący”), za którym stoi wielki dział jego obozowych działań i stanów, reakcji i przeobrażeń. W pewien sposób odzyskujemy te, tak słabo w tych warunkach poznane, kobiece ciała. Nie stanowią one już „tylko" przedmiotu przemocy, ale stanowią centrum uwagi, spersonalizowany podmiot somatyczny. Powiedzieć można, że Simon Pietkiewicz narysowała podmiotowość więźniarek, w jej pracach centralny jest nie lager, który je wyniszcza, ale one same z ich wyniszczeniem, każda ze swoim, i to silnie indywidualnym.

Chcę podkreślić tę różnicę, bo dalekosiężnie rzutuje na styl prowadzenia okołolagrowej refleksji. Umieszczona w jej centrum więźniarska podmiotowość, konkretna, imienna - jak na rysunkach Simon-Pietkiewicz zawsze podpisanych i informujących, kto został przedstawiony (chyba, że artystka nie miała takiej wiedzy) - uniemożliwia uogólniony i do pewnego stopnia wówczas jałowy namysł nad doświadczeniem obozów koncentracyjnych. Jego istotą była ekstremalność i jako skrajność różnicowało się ono diametralnie w zależności od jednostkowych, specyficznych losów, dlatego poza szczególnymi sytuacjami, należy je traktować nie jako ich sumę, ale spektrum różnic, spośród 
których dyferencja płci stanowi podstawowy kwantyfikator. Rysunki SimonPietkiewicz przenoszą uwagę z doświadczania obozu koncentracyjnego jako okoliczności, na sam doświadczający podmiot korporalny, który tutaj istnieje na skrzyżowaniu historii i biologii, a nawet zastanawiam się, czy nie można powiedzieć, że podmiot historyczny jest tutaj głównie biologiczny. Nie tło jest pierwszoplanowe, nie warunki, w które wpleciono postaci, ale one same z ich uwyraźnioną przez rozmaite cierpienia cielesnością. Rola wyeksponowanych somatycznych podmiotów jest doniosła z jeszcze innego powodu - przesądza o możliwości wyobrażenia, a co za tym idzie, zrozumienia doświadczenia historycznego. Ciało nie odwraca uwagi od historii, ale uzmysławia ją w konkretnym, fizycznym, przedstawieniowym (nie pojęciowym) wymiarze.

Przeniesienie uwagi na doświadczenie historyczne, którego centrum stanowi konkretny podmiot somatyczny („,obiekt” makrohistorii) pozwala choć trochę objąć jej skalę, na przykład zbrodniczości nazizmu pastwiącego się na tymi spersonalizowanymi „obiektami” o twarzach z rysunków Simon-Pietkiewicz. Zobrazowany konkretny kobiecy podmiot staje w miejscu bezimienności doświadczenia wyrażonego narracją wielkiej historii, liczbami i statystyką. W sytuacji, w której uogólnienie zaprowadzić by mogło w stronę banału o okrucieństwie nazistów, spotykamy persony więźniarek z ich obozowymi fryzurami, ubraniami, gestami, pozycjami ciała, chorobami, umieraniem (etycznego wymiaru personalizowania historii w tym wypadku uzasadniać nie potrzeba $)^{43}$.

Nihil novi sub sole, refleksja z zakresu antropologii ciała rozwija się prężnie, również w rodzimej humanistyce ${ }^{44}$. Niemniej w dziedzinie badania doświadczenia lagrowego i rozmaitych form jego utrwalania nadal panuje poważny, zasygnalizowany już przeze mnie na wstępie deficyt. Postpamięciowe symbole i metafory, użyteczne dla upowszechnienia wiedzy i wyobrażenia o obozowym specyficznym doświadczeniu kobiet w zasadzie nie istnieją. Takiego celu nie realizują na przykład znane rzeźby Zofii Pociłowskiej-Kann, byłej więźniarki Ravensbrück, pełniące „uniwersalne”, spetryfikowane role

43 Zob. np. S. Ruszkowska, Każdemu własna śmierć, Warszawa 2014.

44 Antropologia ciała. Zagadnienia i wybór tekstów, oprac. A. Chałupnik, J. Jaworska, J. Kowalska-Leder, I. Kurz, M. Szpakowska, wstęp i red. M. Szpakowska, Warszawa 2008; R. Shusterman, Myślenie ciała. Eseje z zakresu somaestetyki, Warszawa 2016; R. Shusterman, Świadomość ciała. Dociekania z zakresu somaestetyki, Kraków 2016; B. Karwowska, Ciało, seksualność i obozy zagłady, Kraków 2009; D. Kulesza, Ciało ludzkie w polskiej literaturze obozowej. Rekonesans, „Ethos” 2008, nr 2/3, s. 175-188. 
memorialne, czy ogólnikowe wyrażenia opierające się na schematach (pomnik w Ravensbrück, Terezinie). Miarą tego deficytu był medialny sukces Krystyny Piotrowskiej (druga dekada XXI wieku) - powieszona na ścianie mandala wykonana przez artystkę ze splecionych kobiecych włosów i utkany z nich Dywan zwróciły uwagę na kobiecy Holokaust i były eksponowane w najważniejszych krajowych galeriach sztuki. A przecież nie można mieć wątpliwości, że kobiece doświadczenie obozów i Holokaustu jest związane nie tylko z włosami. Przez to, co rozgrywało się w związku z indywidualnym kobiecym ciałem, drogą poświęconej jego losowi refleksji dopiero można dojść do „otwarcia”, wykreowania metafor kobiecego doświadczenia lagru. W sferze takich intelektualno-wyobrażeniowych prób i dążeń bezcenny wydaje się potencjał, który wynika z bezpośredniości jego przedstawienia. Na podstawie rysunków Simon-Pietkiewicz dosyć precyzyjnie można odpowiedzieć na pytanie: jakie były te więźniarki, co im dolegało, na jakie niedogodności i cierpienia były narażone; uchwycić to, co charakterystyczne (pozycje ciała, wyrazy twarzy, oczu, gesty), typowość kobiecej egzystencji w lagrze, uzyskać jej konkretyzację. To stanowi o pożądanej „gęstości”, „stężeniu” czy „nasyceniu” tym doświadczeniem, którego intelektualna i artystyczna konceptualizacja może doprowadzić do wypracowania symboli i metafor, stojących w merytorycznej opozycji z płytkością obiegowych wyobrażeń.

Współczesna dyskusja na temat historii w przestrzeni publicznej jest dalece rozbudowana i wielowątkowa, współtworzą ją tematy nie tylko stricte muzealnicze, ale związane z niekonwencjonalnymi miejscami pamięci, a nawet (nie)miejscami pamięci w przestrzeni publicznej, turystyką historyczną i ruchami odtwórstwa historycznego, historycznym performansem, rolą i potencjałem oral history, współczesną archiwistyką i archiwami społecznymi, wizualizacjami historii i jej obecnością w mediach, nie tylko filmie i radio historycznym, ale również na przykład komiksie czy muzyce rozrywkowej, grach planszowych i komputerowych. Wydaje się, że dyskurs ten został w dużej mierze zaanektowany przez rozważania o możliwościach, jakich dostarczają nowoczesne media i technologie oraz ich obiecującej relacyjności ze społeczeństwem, zaś mniej atrakcyjne pozostają dlań archiwalne źródła od wielu lat czekające już na włączenie do porządku interpretowanych materiałów i współczesną konceptualizację w bieżących okolicznościach kulturowych. Nie mniej jednak optymistycznym aspektem większości tych działań 
i perspektyw jest demokratyzacja zakładająca włączenie w dyskurs makrohistorii indywidualnych głosów, twarzy i ciał, takich jak utrwalone w obozowych pracach Jadwigi Simon-Pietkiewicz.

Jak się wydaje, plastyczka odsłoniła je nie tyle powodowana imperatywem dowodzenia niemieckiej zbrodni obozów, ile wiernością artystycznej namiętności. Magnetyzująca widza i absorbująca całość każdego jednostkowego przedstawienia centralność w jej pracach „modelek” - więźniarek zdradza oddanie się bez wyboru portretowanym cielesnym podmiotom, jakby to one przesądzały i decydowały, nie zaś autorka ich wizerunków, która potem napisała: „Wszystkie zdawałyśmy sobie sprawę z beznadziejności naszego położenia. [...] Co do mnie, powiedziałam sobie: niechże ja sobie przedtem trochę porysuję"45.

\section{Bibliografia}

Antropologia ciała. Zagadnienia i wybór tekstów, oprac. A. Chałupnik, J. Jaworska, J. Kowalska-Leder, I. Kurz, M. Szpakowska, wstęp i red. M. Szpakowska, Warszawa 2008.

Czarnecka M., Kiedio E., Zostały mi słowa miłości. Maria Hiszpańska-Neumann: życie i twórczość, Warszawa 2019.

Draus J., Nauka polska na emigracji 1945-1990, [w:] Historia nauki polskiej, t. 10, 1944-1989. Cz. 2: Instytucje, red. L. Zasztowt i J. Schiller-Walicka, Warszawa 2015.

Grzebalska W., Od fałszywego uniwersalizmu do fetyszyzacji różnicy. Historia powstania warszawskiego i rewizjonistyczny „zwrot herstoryczny”, „Pamięć i Sprawiedliwość" 2015, nr 2.

Jaworska J., „Nie wszystek umrę... ...". Twórczość plastyczna Polaków w hitlerowskich więzieniach i obozach koncentracyjnych 1939-1945, Warszawa 1975.

Kaumkötter J., Śmierć nie ma ostatniego słowa. Sztuka w tragicznych latach 1933-1945, przeł. B. Baran, Kraków 2015. 
Barbara Czarnecka, Twórczość plastyczna Jadwigi Simon-Pietkiewicz w obozie koncentracyjnym...

Kruszewski E. S., Instytut Źródłowy w Lund (1939-1972): zarys historii i dorobek, Londyn-Kopenhaga 2001.

Millu L., Dymy Birkenau, przeł. K. i E. Kabatcowie, Oświęcim 2007.

Poczet artystów polskich i w Polsce działających, red. K. Lewicka, B. Osińska, Warszawa 1996.

Winnik S., Dziewczęta z Auschwitz. Głosy ocalonych kobiet, Warszawa 2018. 